Nova Southeastern University

From the SelectedWorks of Debra Moss (Curtis) Vollweiler

February, 2018

\title{
"They're Digging in the Wrong Place." How Learning Outcomes Can Improve Bar Exams and Ensure Practice Ready Attorneys
}

Debra Moss Curtis 


\section{HEINONLINE}

Citation:

Debra Moss Curtis, They're Digging in the Wrong Place

How Learning Outcomes Can Improve Bar Exams and Ensure

Practice Ready Attorneys, 10 Elon L. Rev. 239

(2018)

Provided by:

NSU Shepard Broad College of Law Panza Maurer Law Library

Content downloaded/printed from $\underline{\text { HeinOnline }}$

Mon Aug 27 14:41:35 2018

-- Your use of this HeinOnline PDF indicates your acceptance of HeinOnline's Terms and Conditions of the license agreement available at https://heinonline.org/HOL/License

-- The search text of this PDF is generated from uncorrected OCR text.

-- To obtain permission to use this article beyond the scope of your HeinOnline license, please use:

\section{Copyright Information}

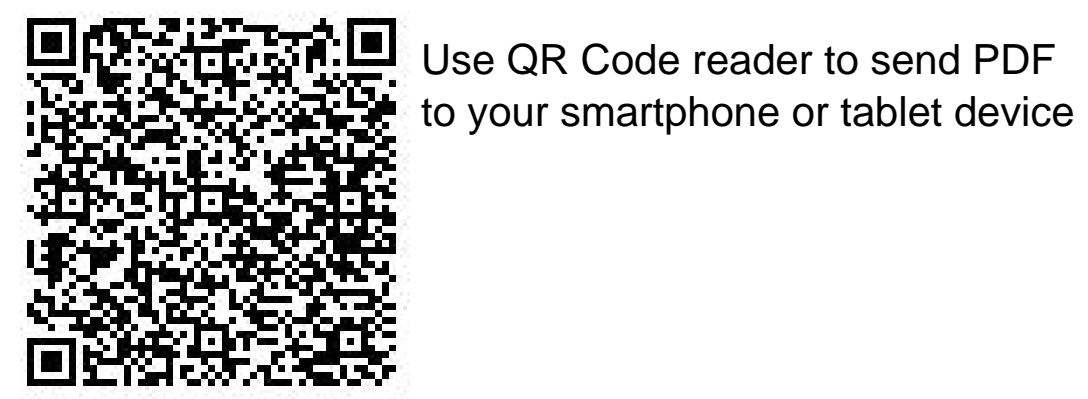




\begin{tabular}{c}
\hline \hline "THEY'RE DIGGING IN THE WRONG PLACE:" \\
HOW LEARNING OUTCOMES CAN IMPROVE BAR EXAMS \\
AND ENSURE PRACTICE READY ATTORNEYS \\
\hline \hline
\end{tabular}

By DEBRA MOSS CuRTIS*

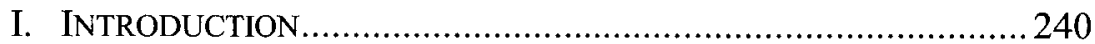

II. OVERVIEW OF THE BAR EXAM NATIONALLY …......................2242

A. Bar Exam Disparity....................................................... 244

B. The Bar exam is a poor predictor of practice/lawyering skills.

C. The drop in overall scores is pushing the law school curriculum away from those practice lawyer skillsexperiential learning - and toward test preparation

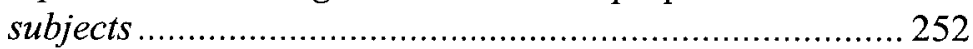

III. LAW SCHOOL CURRICULUM AND TEACHING NECESSARY COMPETENCIES FOR NEW ATTORNEYS ..................................259

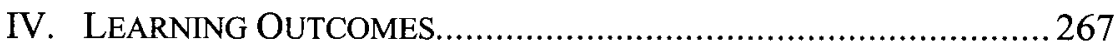

A. Learning Outcomes come to Legal Education .................... 268

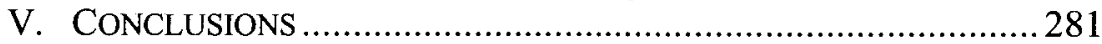

\footnotetext{
*Debra Moss Curtis is a Professor of Law at Nova Southeastern University Shepard Broad College of Law. Special thanks to Dean Christopher Pietruszkiewicz, of Stetson University College of Law, to John Berry, of the Florida Bar, for developing concepts in Vision 2016, to Samantha Gozlan, NSU College of Law class of 2019, for her technical assistance, and to Irma for allowing this work to be completed.
} 


\section{INTRODUCTION}

There is no question that law schools should produce professional, ethical new attorneys who have the skills, knowledge and attributes to be competent and responsible members of their new profession, with the ability to pass the bar exam. However, as it currently stands, these two goalseveryday practical lawyer skills training, and bar exam passage- have become so divided, that many law schools are being pulled in a no-win tugof-war between preparing students for practice or for a memorizationbased, doctrinal heavy exam. This conflict must stop.

The title of this piece was meant to evoke a plot point from the movie Raiders of the Lost Ark. 'At one particular point, both our hero and another group are both searching for the Ark of the Covenant. ${ }^{2}$ Although the other group has an extremely and technically well-organized archeological site, it is determined by our hero that because they are missing a key piece of information, they are in fact "digging in the wrong place." Although there are no heroes or bad guys in this scenario, in many states, the administrators of the bar exam are experiencing the same problem. In seeking to determine minimum competency to practice law, they may be technically testing in a well-organized fashion, but they are ignoring important outside information that would have them testing differently to find out more or different information that would be a better measure of competency for new attorneys. ${ }^{4}$ The bar exam is simply "digging" for competency in the wrong place.

At the same time, the chorus of voices demanding that law schools make necessary steps in the reformation of legal education has risen to a

1 The Headpiece to the Staff of Ra, SHMOOP, https://www.shmoop.com/raiders-of-the-lostark/headpiece-staff-of-ra-symbol.html (last visited Oct. 21, 2017).

2 See id; see also The Ark of the Covenant, SHMOOP, https://www.shmoop.com/raiders-ofthe-lost-ark/ark-of-covenant-symbol.html (last visited Oct. 21, 2017).

3 See The Ark of the Covenant, supra notc 2.

4 See Karen Tokarz et al., Legal Education at a Crossroads: Innovation, Integration, and Pluralism Required, 43 WASH. U. J.L. \& POL'Y 11, 21-22 (2013) (describing the low standards for graduating law students set forth by the ABA). 
fever pitch. ${ }^{5}$ Much has been written about the stagnancy in legal education, ${ }^{6}$ and despite some recent innovations, many law school experiences remain strikingly similar to both each other and to the course of study as it has existed for many years.? However, it is well accepted that the legal profession has changed dramatically, both in the practice, and in the level of training practicing lawyers can give their new hires. ${ }^{8}$ The result is although law schools are "part of a vertically integrated system of production in which the end product is lawyers," this system is suffering a major disconnect in the pipeline. ${ }^{9}$ Law schools seem poised to change, but many are hampered in their efforts by the licensing exam itself. ${ }^{10}$ But through change and cooperation, we can fix this disconnect.

This Article argues for an alignment of the bar exam with the needs of the legal profession, using learning outcomes as a tool to include all the skills, knowledge and attributes of a professional, successful new attorney in cooperation with assessment by law schools. Part II gives an overview of the bar exam nationally. Part III discusses legal education, and why the bar exam is misaligned with it. Part IV discusses learning outcomes, and offers them as a solution to better align legal education, the bar exam, and the practice of law to allow new lawyers to be truly competent. Part V concludes this work.

5 See Christine P. Bartholomew, Time: An Empirical Analysis of Law Student Time Management Deficiencies, 81 U. CIN. L. REV. 897, 900 (2013) (elaborating on the ABA's request for time management training within the profession).

6 See Alfred S. Konefsky \& Barry Sullivan, In This, the Winter of Our Discontent: Legal Practice, Legal Education, and the Culture of Distrust, 62 BUFF. L. REV. 659, 661 (2014) (addressing the inexcusable complacency within legal education standards).

7 See Preparing Lawyers for Practice: Legal Education for the Real World, 1, PROFESSIONALISM IN THE 21ST CENTURY 1, 1-2 (2015), https://thepractice.law.harvard.cdu/article/preparing-lawyers-for-practice/.

${ }^{8}$ David Barnhizer, Redesigning the American Law School, 2010 MICH. ST. L. REV. 249, 260.

${ }^{9}$ Id.

10 See Beau Steenken, Outcomes in the Balance: The Crisis in Legal Education as a Catalyst for Change, 19 AALL SPECTRUM 10,10 (2015) (describing how low bar passage rates hurt both the profession and law school admissions). 


\section{OVERVIEW OF THE BAR EXAM NATIONALLY}

There is a "growing chorus of critics" who are challenging whether the current knowledge focused bar exam is the best way to protect the public in licensing new attorneys. ${ }^{11}$ In fact, some have said that the traditional bar exam and licensing practices have outlived their usefulness. ${ }^{12}$ Even in the middle of the crisis occurring in California, ${ }^{13}$ focusing on the appropriate cut score of one of the most notoriously difficult bar exams, the larger question is being asked-"Does the exam even test what incoming lawyers need to know?"

At the same time, legal education now has to account for students' bar examination results, as per the current ABA Standard:

\section{Standard 316. BAR PASSAGE}

(a) A law school's bar passage rate shall be sufficient, for purposes of Standard 301(a), (Standard 301. OBJECTIVES OF PROGRAM OF LEGAL EDUCATION (a) A law school shall maintain a rigorous program of legal education that prepares its students, upon graduation, for admission to the bar and for effective, ethical, and responsible participation as members of the legal profession. if the school) if it demonstrates that it meets any one of the following tests:

(1) That for students who graduated from the law school within the five most recently completed calendar years:

(i) 75 percent or more of these graduates who sat for the bar passed a bar examination; or

11 Eileen Kaufman et al., A Better Bar Exam - Look to Upper Canada, L. SCH. CAFE (July 25, 2017), https://www.lawschoolcafe.org/2017/07/25/a-better-bar-exam-look-to-upper-canada/.

12 See Nicholas W. Allard, The Bar Exam is Not the Best Test of a Good Lawyer, N.Y. TiMES (Sept. 24, 2015), https:/www.nytimes.com/roomfordebatc/2015/09/24/is-the-bar-too-low-toget-into-law-school/the-bar-exam-is-not-the-best-test-of-a-good-lawyer?mcubz=0.

13 See generally Dan Walters, Law school enrollment, bar exam passage rate dropping in California, SACRAMENTO BEE (Feb. 18, 2017), http:/www.sacbee.com/news/politics-government/politics-columns-blogs/dan-walters/article133493754.html (explaining the various conflicts ensuing within the California State Bar, and discussing California's dropping bar exam pass rates and falling law school enrollment).

14 Paul L. Caron, WSJ: Deans Push To Lower California Bar Pass Score, but Lawyers with Lower Scores are More Likely to be Disciplined or Disbarred, TAXPROF BLOG (May 31, 2017), http://taxprof.typepad.com/taxprof_blog/2017/05/wsjdeans-push-to-lower-california-barexam-passing-score-but-lawyers-with-lower-scores-are-more-like.html.

15 See Jerry Anderson \& Erin E. Lee Schneider, Clearing the Final Hurdle: Law Schools and the Bar Exam, 77 IOWA LAW. 7, 7-8 (2017) (explaining the scrutiny applied to bar results by the ABA). 
(ii) in at least three of these calendar years, 75 percent of the students graduating in those years and sitting for the bar have passed a bar examination. OR

(2) That in three or more of the five most recently completed calendar years, the school's annual first-time bar passage rate in the jurisdictions reported by the school is no more than 15 points below the average firsttime bar passage rates for graduates of ABA-approved law schools taking the bar examination in these same jurisdictions.

*A school shall be out of compliance with this Standard if it is unable to demonstrate that it meets the requirements of paragraph (a)(1) or (2) ${ }^{16}$

However, under a new proposed standard, the accountability increases; the proposed new Standard provides as follows: At least $75 \%$ of a law school's graduates in a calendar year who sat for a bar examination must have passed a bar examination administered within two years of their date of graduation. ${ }^{17}$ Such rule is still under consideration. ${ }^{18}$

Overall only four law schools have been impacted in the accreditation process in any way due to bar exam passage rates. ${ }^{19}$ However, the ABA regulation of law schools has received criticism. In June 2016, a Department of Education panel recommended that the $A B A$ be suspended from accrediting new law schools for a year, and although this suspension did not happen, it raised concerns about the effectiveness of the standards, and whether they are being enforced. ${ }^{20}$ With new, tougher standards on the table, law school accountability for bar exam results are being highly scrutinized, if not by regulators, then by the public.

16 A.B.A., 2017-2018 STANDARDS AND RULES OF PROCEDURE FOR APPROVAL OF LAW SCHOOLS 24 (2017) [hereinafter A.B.A. STANDARDS], https://www.americanbar.org/groups/legal_education/resources/standards.html.

${ }_{17}$ Rebecca White Berch, Council Business: Proposed Changes to the Bar Pass Standard and to Foreign Site Visit Requirements, 47 SYLLABUS 1 (2016), https://www.americanbar.org/publications/syllabus_home/volume-47-2015-2016/syllabus-summer-2016-47-4-/from-thechair.html.

18 See Stephanie Francis Ward, ABA House rejects proposal to tighten bar-pass standards for law schools, A.B.A. J. (Feb. 6, 2017), http://www.abajournal.com/news/article/aba_house_rejects_proposal_to_tighten_bar_pass_standards_for_law_schools ("The ABA House of Dclegates voted against a proposal to tighten bar passage rate standards for accredited law schools. The house can send the proposed rule back to the Council of the Section of Legal Education and Admissions to the Bar twice for review with or without recommendations, but the council has the final decision on Standard 316 ...").

${ }_{19}$ See Mark Hansen, Bar Fight, 102 A.B.A. J. 48, 54 (2016).

${ }^{20} \mathrm{Id}$. 
The bottom line is that these tougher standards have become the law school's business in determining how students do on the bar exam, ${ }^{21} \mathrm{de}-$ spite the fact that bar exams nationwide are incredibly diverse and disconnected from legal education. ${ }^{22}$ While accountability to licensing students at the end of their law school experience is not a bad thing, the problem comes when a licensing exam is changing the substance of legal education, but is not, itself, a clear measure of competency for practice. One challenge in solving this disconnect is addressing the disparity of bar exams itself.

\section{A. Bar Exam Disparity}

As of September 2017, out of 51 jurisdictions, 29 have adopted the Uniform Bar Exam (UBE). ${ }^{23}$ For these jurisdictions, the UBE offers a testing framework, while allowing for state differences as to cut scores, state specific components, and character and fitness analysis. ${ }^{24}$ The test itself is built with common portions - the Multistate Bar Exam, a six hour, 200 multiple choice question portion that encompasses the following subjects nationally (worth 50\%): Civil Procedure, Constitutional Law, Criminal Law and Criminal Procedure, Contracts, Torts, Real Property and Evidence. ${ }^{25}$ The second common day of testing has two parts. First, the Multistate Essay Examination Test (worth 30\%), including the following general subjects: Business Associations; Civil Procedure, Conflict of Laws, Constitutional Law, Contracts, Criminal Law and Criminal Procedure, Evidence, Family Law, Real Property, Torts, Trusts and Estates, UCC: Article 9, and a second part, the Multistate Performance Test (MPT) (worth $20 \%$ of total) ${ }^{26}$ The MPT is designed to test an examinee's ability

21 See generally id. (explaining how standards have made it the law school's business in determining how law students do on the bar exam).

22 See id.; see also Dennis R. Honabach, To UBE or not to UBE: Reconsidering the Uniform Bar Exam, 22 PROF. LAW. 42 (2014) (discussing the disconnectedness and diversity of the Bar Exam).

${ }^{23}$ Adoption of the Uniform Bar Examination with NCBE Tests Administered by Non-UBE Jurisdictions, NAT'L CONF. $\quad$ B. http://www.ncbex.org/pdfviewer/?file=\%2Fdmsdocument $\% 2$ F 196 (last visited May 8, 2017).

24 Understanding the Uniform Bar Examination, NAT'L CONF. B. EXAMINERS, http:/www.ncbex.org/pdfviewer/?file $=\% 2$ Fdmsdocument $\% 2$ F209 (last visited May 8, 2017).

25 Preparing for the MBE, NAT'L CONF. B. EXAMINERS, http://www.ncbex.org/exams/mbe/preparing/ (last visited May 8, 2017).

26 Preparing for the MEE, NAT'L CONF. B. EXAMINERS, http:/www.ncbex.org/exams/mee/preparing/ (last visited May 8, 2017). 
to use fundamental lawyering skills in a realistic situation and complete a task that a beginning lawyer should be able to accomplish. ${ }^{27}$ The MPT is developed by NCBE and consists of two 90 -minute segments, such as a case file in which a memo needs to be drafted. ${ }^{28}$ The MPT is not a test of substantive knowledge, but rather, it is designed to evaluate certain fundamental skills lawyers are expected to demonstrate regardless of the area of law in which the skills arise. ${ }^{29}$

One benefit of the UBE is the ability to "port" one's score to other jurisdictions. ${ }^{30}$ A porting window is a time frame set by each state that has adopted the UBE, which allows an applicant to apply for bar admission in that state using a score on the UBE taken in any UBE jurisdiction. ${ }^{31}$ To port a score, an applicant must not only have a cut score high enough for that state's requirements, but the applicant must also proceed through the remaining state bar admission requirements, which could include character and fitness screening, a state specific testing portion, pro bono service, or other requirements. ${ }^{32}$

There has been a recent explosion of the use of the UBE, leading to a very critical look at that instrument and its adoption. ${ }^{33}$ Although noted benefits of the UBE include fewer tested doctrinal subjects, portability, and better developed instruments than many individual states have been able to provide, criticism of the UBE and its respective parts has been widespread and frequent. ${ }^{34}$

One analysis of the UBE states that it sustains and reinforces "an anachronistic over-emphasis on general subject matter knowledge just at the moment when we should all be dynamically shifting focus and resources toward experiential learning and training skills. ${ }^{35}$ The argument is that the UBE is not helping skills training flourish nationwide due to the

\footnotetext{
27 Jurisdictions Administering the MPT, NAT'L CONF. B. EXAMINERS, http://www.ncbex.org/exams/mpt/ (last visited May 8, 2017).

${ }^{28}$ Preparing for the MPT, NAT'L CONF. B. EXAMINERS, http://www.ncbex.org/exams/mpt/preparing/ (last visited Oct. 23, 2017).

29 Jurisdictions Administering the MPT, supra note 27.

30 Honabach, supra note 22 , at 45.

31 Id. at 44-46.

32 Id.

33 Id. at 43-44.

34 See generally id. (discussing the benefits and criticisms of the UBE).

$35 \mathrm{Id}$. at 44 .
} 
continued primary focus on content knowledge and rule memorization. ${ }^{36}$ This criticism suggests that the entire format should be revised to test real competencies, and that adoption of the UBE by so many states means doubling down acceptance on doctrine and subject matter coverage as the primary means of testing. ${ }^{37}$ Some have called "the most negative consequence" of the UBE the continued assurance that a "substantial portion of a law student's legal education will be spent on learning content rather than on learning skills and values they will need to be effective lawyers." ${ }^{, 38}$

While the UBE continues the trend of requiring widespread memorization testing, this criticism overlooks two important points. First, that the number of subjects that examinees must learn for this exam is far fewer than the exams of many other states. This results in students spending less time on this type of doctrinal knowledge during law school. Second, that the UBE, unlike many state exams, contains the Multistate Practice Test portion, which decreases the percentage of testing based on non-experiential skills in states that have not adopted the UBE. ${ }^{39}$ Again, the primary focus of the UBE is defining minimum competency and driving education and licensing in the pursuit of such competency.

Another criticism of the UBE has been that it tests areas of law that are not the specific law in the state of the applicant. ${ }^{40}$ However, the UBE allows separate assessment of state law as part of the component for admission to any UBE adopting state. ${ }^{41}$ For example, in Missouri, the regulators added a Missouri law component called the Missouri Educational Component Test (MECT). ${ }^{42}$ The MECT is an online, multiple-choice exam that must be taken and passed in addition to the UBE for bar admission. ${ }^{43}$ While it has been questioned whether this test "meaningfully exposes applicants" to Missouri law due to the ability to retake questions with feedback, it is not pedagogically different than rote pre-test memorization in other states. ${ }^{44}$ Other states handle state law testing differently,

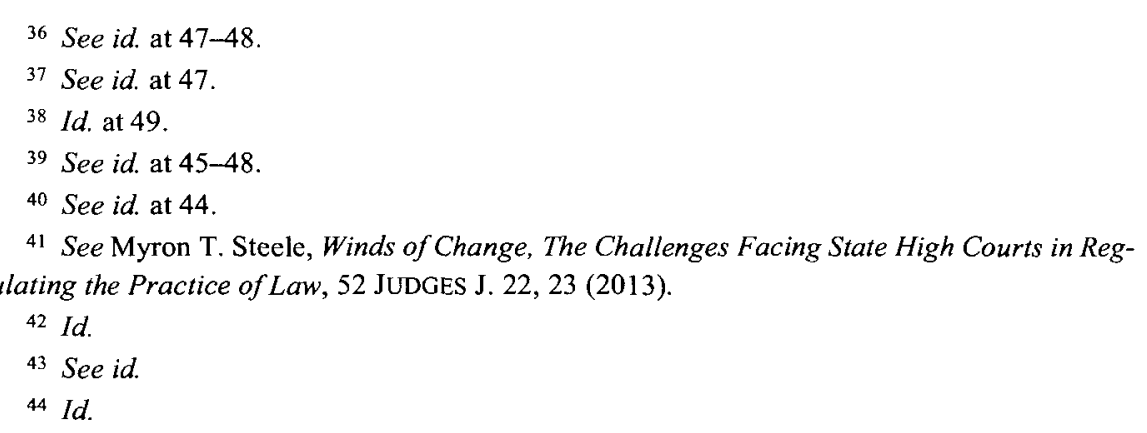


such as Alabama, who requires additional state specific essays, or Arizona, which requires a six-hour course on Arizona law. ${ }^{45}$ New York has added a necessary component of state specific testing by requiring applicants to enroll in the New York Law Course, which applicants must complete up to one year before, or any time after, the applicant sits for the UBE. ${ }^{46}$ This course leads to the New York Law Exam, which is a 50 item, two-hour open book multiple-choice test administered online on the New York rules. ${ }^{47}$

Further, there has been criticism that a passing score in one jurisdiction does not guarantee a passing score in another jurisdiction, so critics argue that the portability of score benefit is illusory. ${ }^{48}$ However, the benefit of taking a single bar exam in an attempt to attain the highest possible score, which triggers application for admission in multiple UBE adopted states, still outweighs the trouble of having to take multiple exams. This is so, despite that the choices may be limited due to varying cut scores and windows of portability of the score over time.

Of the remaining non-UBE jurisdictions, all but one jurisdiction use the Multistate Bar Exam (MBE) for day one of its testing. ${ }^{49}$ However, the remaining jurisdictions have great diversity in the subjects and methods tested on day two. ${ }^{50}$ For example, in Florida, depending on how you count them (as a bar subject or a law school taught subject), there are up to twenty-three different subjects tested on the state portion of the exam, which are split evenly between multiple-choice and essays. ${ }^{51}$ Additionally, other states, while not adopters of the UBE, are considered to be "users" of the other parts of the UBE, such as using the MPT or the MEE.

45 See id.

46 See Uniform Bar Examination, New York Law Course \& New York Law Exam, N.Y. ST.

BD. L. EXAMINERS, https://www.nybarexam.org/UBE/UBE.html (last visited Oct. 16, 2017).

47 See id.

48 See Honabach, supra note 22, at 47.

49 See Adoption of the Uniform Bar Examination, NAT'L CONF. B. EXAMINERS (Nov. 28, 2017), http:/www.ncbex.org/pdfviewer/?file $=$ http $\% 3 \mathrm{~A} \% 2 \mathrm{~F} \% 2 \mathrm{Fwww}$.ncbex.org $\% 2 \mathrm{Fdmsdocu}-$ ment\%2F196 (providing that Louisiana is the only state that has not adopted the UBE nor the Multistate Bar Exam).

50 See Bar Examination Preparation: General Information, U. ST. THOMAS (June 6, 2017), http://libguides.stthomas.edu/Bar_Exam_Study.

51 Exam Information, Test Specifications, Study Guide, and Virtual Tour, FLA. BD. B. EXAMINERS, https:/www.floridabarexam.org/web/web site.nsf/52286AE9AD5D845185257C07005C3FE1/125BA5AFD5EB7D2385257C0B0067E7 48 (last visited Oct. 16, 2017) [hereinafter Virtual Tour]. 
This allows those states to ensure that a portion of their state specific day is tested alongside an otherwise self-drafted and graded exam. For example, the Illinois Bar non-MBE day includes two three-hour segments comprised of one 90-minute MPT test, as well as Illinois specific essays. ${ }^{52}$ The other three-hour segment includes six essays from the MEE, for a total of 24 total subjects possibly tested. ${ }^{53}$ In Maryland, there are only 12 subjects tested by way of 10 state essay questions and one MPT test. ${ }^{54}$

In short, different states put focus on the amount of doctrinal-tested material, different proportions of state versus foundational law, different methods of testing, and different formats. Yet, law schools are all held to the same accreditation standards regarding the pass rate. ${ }^{55}$ Additionally, in recent years, despite a lack of empirical evidence to protect the public by ensuring better qualified lawyers, many states have raised the passing score (cut score) needed for admission to the bar, under exactly that guise-ensuring better qualified lawyers. ${ }^{56}$ It is possible for states to manipulate the individual tests and/or cut scores to impact the passage rate of students, which, in turn, directly affects law schools' viability. ${ }^{57}$

It is in this way that the disparity of bar exams nationwide is directly impacting legal education. It has been suggested that overall, bar examiners have no interest in making it easier for anyone to pass a bar exam, and that the profession has an economic self-interest in keeping lawyers out. ${ }^{58}$

52 See Illinois Bar Exam Information, ILL. BD. ADMISSIONS TO THE B. (2011), http:/law.wisc.edu/academicenhancement/statebarreqs/il.pdf.

53 See id.

54 See Comparison of Topics Tested in Maryland and on the UBE, UNIFORM B. EXAMINATION ADVISORY COMM., http://mdcourts.gov/coappeals/ube/pdfs/topicstestedcomparisonchart.pdf (last visited Oct. 19, 2017).

55 See A.B.A., Section of Legal Educ. \& AdMissions to the BAR, THE LAw SCHOOL ACCREDITATION PROCESS 7 (2016), https://www.americanbar.org/content/dam/aba/publications/misc/legal_education/2016_accreditation_brochure_final.authcheckdam.pdf (describing the standards required of all A.B.A. approved law schools to retain accreditation).

56 See Andrea A. Curcio, A Better Bar: Why and How the Existing Bar Exam Should Change, 81 NEB. L. REV. 363, 369 (2002).

57 See Bar Exam Difficulty, L. SCH. TRANSPARENCY, https://www.lawschooltransparency.com/reform/projects/investigations/2015/data/other-stats/?show=cutscores ("The 'cut score' is the minimum passing score as set by each individual state.") (emphasis added) (last visited Oct. 23, 2017).

58 See generally Andrew M. Perlman, A Bar Against Competition: The Unconstitutionality of Admission Rules for Out-of-State Lawyers, 18 GEO. J. LEGAL ETHICS 135, 147-48 (2004) (discussing the influence of economic self-interest on bar admissions). 
This protectionist viewpoint and approach by bar examiners also contributes to the desire to keep lawyers from being admitted to other states without retesting. ${ }^{59}$ The national and global changes to the practice of law have been noticed by those in the fight to loosen bar admission rules in federal district court, with some commenting that "if the bar doesn't adjust to these realities, it's going to look increasingly like its primary focus is not on ensuring the competence of legal practitioners but on protecting its members from competition." ${ }^{\text {"60 }}$ The time to adjust to these realities is now. A uniform standard of passage for all law schools, disconnected from the ability of individual state bar examiners to so heavily influence who passes the exam, is a potentially dangerous combination.

\section{B. The Bar exam is a poor predictor of practice/lawyering skills}

It cannot be overstated that the common rationale for the power vested in boards of bar examiners to regulate the legal profession is to "protect the public" from incompetent practitioners, or some variation on that statement. ${ }^{61}$ The ABA Model Rules of Professional Conduct list "minimal competency" as the first standard, and the bar exam is certainly part of that gate-keeping function. ${ }^{62}$ The Board of Bar Examiners states that it is protecting the public and the profession by ensuring this competency. ${ }^{63}$ The licensing test may be the tool used most often to test such competency and, in some states, the only means in which it is done. ${ }^{64}$ The debate on whether this test accomplishes the goal of minimum competency is not new, but has been brought further into the limelight with the dawning of the new legal education age of today, where we fully consider more than doctrinal knowledge in what makes a competent lawyer. ${ }^{65}$ The problem lies squarely in the definition of what constitutes "minimum competency." The bar exam has one primary focus: doctrine. But the profession requires a wide variety of other skills, both legal and non-legal, of all

\footnotetext{
59 See id.

60 David L. Hudson, Jr., Tear Down This Wall, 102 A.B.A. J. 22, 22 (2016).

61 See Michael G. Swansburg, Jr., A Soldier's Heart and A Lawyer's Mind: An Argument for Granting Reciprocity to America's Former Jag Attorneys, 48 U. LOUISVILLE L. REV. 613, 623 (2010).

62 Id. at 623-24.

63 See id. at 624.

64 See id.

65 See id. (noting the ongoing debate surrounding the efficacy of bar exams).
} 
types, in determining competency to become a member of the profession. The test and the profession simply do not align.

The practice of law requires competencies that have never before been considered part of the law school experience. These will be discussed in the next two sections, and include varied needs, such as professional identity, time management, cultural competency and self-directed learning. The majority of bar exams test the following things: subject matter knowledge, memorization, and analysis of facts based on memorized law. Bar exams are designed to measure "baseline knowledge," which should no longer be considered a synonym for minimum competence. By contrast, many critics have long pointed out some of the skills that bar exams fail to include, such as knowing the right questions to ask (e.g., a typical bar exam question gives all the facts and asks for a resolution based on the memorized law), interviewing, counseling, examining witnesses, and legal research. ${ }^{66}$ The disconnect is easy to see.

Although acknowledging that foundational knowledge is an important component of minimum competency, the bar exam has been criticized on the basis of whether asking obscure questions in basic subjects really appropriately measures minimum competency. ${ }^{67}$ Additionally, anyone who has studied for this exam knows two truths: (1) much of the knowledge doesn't stay with people after the exam, and (2) even if it does, the law changes and lawyers must constantly keep up with it (a skill not measured on the exam itself). One scholar found these questions in recent bar exams:

Examples of the kinds of information examinees are expected to know include:

- the appropriate remedy in an action for conversion;

- whether a kidnap victim must know she has been kidnapped in order for the State to bring a kidnapping or attempted kidnapping charge;

- whether a notation in a medical record stating "patient says he was attacked by ' $\mathrm{X}$ " is admissible to prove that " $\mathrm{X}$ " was the attacker;

${ }^{66}$ See Stephen P. Klein, Relationship of Bar Examinations to Performance Tests of Lawyering Skills 1, RAND CORP. (July 1983), http://www.rand.org/content/dam/rand/pubs/papers/2009/P6895.pdf.

${ }^{67}$ See generally Ben Bratman, Improving the Performance of the Performance Test: The Key to Meaningful Bar Exam Reform, 83 UMKC L. REV. 565 (2015) (describing common criticisms aimed at bar exams). 
- whether, as a matter of constitutional law, a senator and her aide have immunity for statements the senator made during a speech on the senate floor.

Another criticism of testing largely foundational knowledge is the format of the questions used on a bar exam being unrelated to how lawyers actually apply their legal knowledge in practice. "No practicing lawyer has ever been asked to choose one of the 'most correct' of four given answers after being given 1.8 minutes to apply a memorized legal principle to a set of facts she has never seen before." 69

The argument that the bar exam fails to "test an applicant on the qualities most needed in the profession: the ability to communicate and the capacity to make sound decisions" is again, not new. ${ }^{70}$ In fact, a 1992 $\mathrm{ABA}$ Task force indicated that "if anything the bar examination discourages the teaching and acquisition of many of those [fundamental lawyering] skills, such as problem solving, factual investigation, counseling and negotiation, which the traditional examination questions do not attempt to measure.",

For a long time, legal education was able to rely on the profession to conduct appropriate mentoring to ensure the missing skills were filled in by their graduates. ${ }^{72}$ In today's job market, however, new graduates are neither receiving this extensive mentoring, nor have clients been willing to pay for them to learn the trade on their dime. ${ }^{73}$ In Section III, the disparity between the goals of law schools in developing modern attorney competencies and the bar exam will be more fully developed. ${ }^{74}$

68 Curcio, supra note 56, at 375 n.49 (citation omitted).

69 Id. at 376 (citation omitted).

${ }^{70}$ Michael G. Swansburg, Jr., A Soldier's Heart and A Lawyer's Mind: An Argument for Granting Reciprocity to America's Former Jag Attorneys, 48 U. LOUISVILLE L. REV. 613, 625 (2010) (citing Deborah L. Rhode, Institutionalizing Ethics, 44 CASE W. RES. L. REV, 665, 690 (1994)).

71 Id. at 625-26 (quoting A.B.A., SECTION OF LEGAL EDUC. \& AdMISSIONS TO THE BAR, TASK FORCE ON LAW SCHOOLS \& THE PROFESSION-NARROWING THE GAP 278 (1992)).

72 See generally Susan Katcher, Legal Training in the United States: A Brief History, 24 WIS. INT'L L.J. 335, 336-53 (2006) (explaining the history and development of legal education in the United States).

73 See Nicole Black, Things You Didn't Learn in Law School: The Importance of Mentors, MYCASE BLOG (Dec. 10, 2013), https:/www.mycase.com/blog/2013/12/things-didnt-learnlaw-school-importance-mentors/.

74 See infra Section III. 
C. The drop in overall scores is pushing the law school curriculum away from those practice lawyer skills-experiential learning-and toward test preparation subjects

Law schools have made substantial innovations in providing experiential learning in recent years. ${ }^{75}$ There has been an explosion of clinical opportunities, field placement opportunities, and simulation classes. Nevertheless, some institutions are finding that students, feeling the pressures of the doctrine based bar exam, are not taking advantage of these opportunities to the fullest extent while in law school. In short, students have so few available credits during their time in law school, that if they are on a course of study to prepare for passing the bar exam, they may run out of academic class time beyond bar tested courses and exam preparation.

A way to demonstrate this is by looking at our students at NSU College of Law and the courses we offer that students typically enroll in for the primary purpose of preparing for the Florida Bar Examination, among other requirements. ${ }^{76}$ The credit hours associated with these courses are also provided. When a course does not address a bar-tested subject or is duplicated with a course listed elsewhere in the chart, it is listed with " $\mathrm{x}$ " for the credit hours. Starting with the premise that the ABA requires 83 credit hours for graduation, and that NSU Law requires 90 credit hours for graduation, the following chart represents what an NSU College of Law student's credit allocation would look like taking all available courses that aligned with the MBE and the Florida Bar exam subject matter, as well as other requirements for graduation, either generated from our curriculum or $\mathrm{ABA}$ requirements:

\begin{tabular}{|l|l|l|}
\hline Bar Subject & Course & Credit Hours \\
\hline MBE: Civil Procedure & Civil Procedure & 4 \\
\hline $\begin{array}{l}\text { MBE: } \\
\text { Constitutional Law }\end{array}$ & Constitutional Law I & 4 \\
\hline & Constitutional Law II & 3 \\
\hline MBE: Contracts & Contracts & 4 \\
\hline
\end{tabular}

75 See Margaret Loftus, Law Schools Innovate with Hands-On Learning, U.S. NEwS (Mar. 30, 2016, 9:30 AM), https://www.usnews.com/education/best-graduate-schools/top-lawschools/articles/2016-03-30/law-schools-innovate-with-hands-on-learning.

76 Debra Moss Curtis, No Shots, No School, No Kidding: The Legal Profession Needs a Vaccine to Ensure Professionalism, U. FLA. J.L. \& PUB. POL'Y (forthcoming 2017). 


\begin{tabular}{|l|l|l|}
\hline (incl. UCC Article 2) & & \\
\hline $\begin{array}{l}\text { MBE: Criminal Law and } \\
\text { Criminal Procedure }\end{array}$ & UCC: Sales & 2 \\
\hline & Criminal Law & 4 \\
\hline MBE: Evidence & Criminal Procedure & 3 \\
\hline MBE: Real Property & Evidence & 4 \\
\hline & Property & 4 \\
\hline MBE: Torts & Real Estate Transactions & 3 \\
\hline FL: UCC: Article 3 & Torts & 4 \\
\hline FL: UCC: Article 9 & Negotiable Instruments & 3 \\
\hline FL: Business Entities & Secured Transactions & 2 \\
\hline & Business Entities & 4 \\
\hline FL; Criminal Law & Nonprofit Organizations & 3 \\
\hline FL: Civil Procedure & & $\mathrm{X}$ \\
\hline $\begin{array}{l}\text { FL: Criminal Procedure } \\
\text { Rules }\end{array}$ & & $\mathrm{X}$ \\
\hline $\begin{array}{l}\text { FL: Federal Constitutional } \\
\text { Law }\end{array}$ & & $\mathrm{X}$ \\
\hline FL: Constitutional Law & Florida Constitutional Law & 3 \\
\hline FL: Contracts & & $\mathrm{X}$ \\
\hline FL: Evidence & & $\mathrm{X}$ \\
\hline $\begin{array}{l}\text { FL: Family Law and De- } \\
\text { pendency }\end{array}$ & Family Law & 3 \\
\hline & Dependency & $\mathbf{X}$ \\
\hline Juvenile Delinquency & Juvenile Law & 2 \\
\hline Prof. Resp. - Ch. 4 \& 5 & & 3 \\
\hline Professionalism & & $\mathrm{X}$ \\
\hline FL: Real Property & Medical Malpractice & $\mathrm{X}$ \\
\hline FL: Torts & Remedies & 2 \\
\hline & Wills and Trust & 3 \\
\hline $\begin{array}{l}\text { Trusts and Wills and Ad- } \\
\text { ministration of Estates }\end{array}$ & Professional Responsibility & 3 \\
\hline MPRE Exam & FL and Multistate Lab & 3 \\
\hline Exam Preparation Generally & 2 \\
\hline $\begin{array}{l}\text { Upper Level Writing Re- } \\
\text { quirement (see below) }\end{array}$ & $\begin{array}{l}\text { Various courses, including semi- } \\
\text { nars, independent research, or law } \\
\text { review note }\end{array}$ & 2 \\
\hline $\begin{array}{l}\text { First Year Legal Writing } \\
\text { Requirement }\end{array}$ & Legal Research and Writing \\
\hline $\begin{array}{l}\text { ABA Experiential Learning } \\
\text { (see below) }\end{array}$ & $\begin{array}{l}\text { Various workshops, clinics and } \\
\text { field placements (part-time is } 3-6\end{array}$ & 6 \\
\hline Total & & 6 \\
\hline
\end{tabular}


If students were to enroll in all the courses that assist them in preparing for the Florida Bar Exam, as well as the ABA required minimum of experiential credits, they would have to take 91 credit hours, without choosing any other electives or additional experiential learning opportunities.

If a student followed this schedule, the only place where they would have courses crafted as full experiential experiences are the six credits of experiential learning (which could only overlap with one of the courses listed in the chart). Therefore, it is possible that only $7 \%$ of the credits necessary to graduate and prepare for the bar exam could be devoted to experiential education. The marketplace demand for graduates who are better prepared for practice requires more than the six-hour minimum currently required for accreditation purposes. But the bar exam says differently.

The end result is that there is no question that the concern for being prepared for a doctrinal-heavy bar exam is exerting pressure on the law school curriculum as a whole. It is not suggested here to make it easier to become a lawyer by making any bar exam easier to pass. To the contrary, in many ways, suggested changes to the bar exam could make it more difficult for some to pass, which include remaining rigorous in doctrine, and either testing them more deeply, or adding additional skills testing instead of doctrine. In any instance, a reduction in doctrinal testing would allow law students to focus more on the skills needed for practice while in law school-whether or not actually tested on the bar exam.

In Florida, reviews of what makes an attorney minimally competent through the bar exam have focused largely on doctrinal testing. In Florida, in 1925 , there were certainly subjects that would seem foreign to today's law students: the common law of England, pleading and practice in equity, and statutory construction, to name a few. ${ }^{77}$ In 1960 , that list was cut down from 23 subjects to far fewer, including Contracts, Constitutional Law, Federal and State, Wills and Administration of Estates and Trusts, Criminal Law and Procedure, Corporations, Real Property, Evidence, Torts and The Florida Rules of Civil Procedure. ${ }^{78}$ Ten years later, the list was purportedly expanded to ten subjects, but the only change was to consider

\footnotetext{
77 See Bar Examination Subjects Historically (on file with the Elon Law Review).

${ }^{78}$ See id.
} 
Trusts as a separate subject. ${ }^{79}$ In fact, counting from the law school perspective, these are conservatively a dozen different subjects. In 1975, after the MBE was added, the Rules of the Florida Supreme Court relating to admission of the bar ${ }^{80}$ tracked only the following subjects: Florida Constitutional Law, Corporations, Federal Constitutional Law, Florida Rules of Civil and Criminal Procedure, Wills and Administration of Estates, and Trusts. ${ }^{81}$ Not only were there six separate subjects listed (even constitutional law was separated), but the other subjects were eliminated. ${ }^{82}$

In 1977, a further separation and expansion of subjects began. ${ }^{83}$ It was noted that the Florida Rules of Civil and Criminal Procedure and Florida Constitutional Law would be tested on every exam, in addition to Torts, Evidence and Real Property (all subjects tested on the MBE) being added back in. Also, Corporations was expanded to include Business Entities, which topics therein included Corporations and Partnerships. ${ }^{84}$ Over the next decades, the expansion continued. In 1984, Criminal Law, Contracts and Family Law were added. ${ }^{85}$ In 1995, further additions were made ${ }^{86}$ In addition to the Florida Rules of Civil and Criminal Procedure, select rules from the Florida Rules of Judicial Administration were indicated to be tested every exam. ${ }^{87}$ Florida Constitutional Law was no longer listed as being tested on every exam, and Chapter 4 and 5 of the Rules Regulating the Florida Bar, those relating to Professional Conduct, and Trust Accounting were added. ${ }^{88}$

More than a decade later, in 2007, the only change to the Florida Bar Exam was to separate out Chapters 4 and 5 as distinct subjects. ${ }^{89}$ However, the largest leap in many years came in 2010 , when Criminal Law was further expanded to include constitutional criminal procedure and juvenile delinquency. Also, Articles 3 and 9 of the Uniform Commercial Code were added, and Family Law was expanded to include dependency, and

\footnotetext{
${ }^{79} \mathrm{Id}$.

${ }^{80}$ See FLA. SUP. CT. BAR ADMISS. R. 1, et seq.

${ }^{81}$ See Bar EXAmination SUBJeCtS Historically (on file with the Elon Law Review).

82 See id.

$83 \mathrm{Id}$.

${ }_{84} \mathrm{Id}$.

${ }^{85}$ Id.

${ }^{86}$ Id.

87 See id.

88 Id.

${ }^{89}$ Id.
} 
Professionalism was added as a subject. ${ }^{90}$ Per the Florida Bar, there are 16 subjects tested. ${ }^{91}$ From the law school curriculum perspective, these are more than 20 subjects, with enough credits to fill an entire student's entire time in law school, as demonstrated.

Some consideration to skills testing has been given in bar exam discussions. ${ }^{92}$ The Florida Board of Bar Examiners convened a commission that reviewed a task force report from 2008 on the Multistate Performance Test, including the logistics of implementing such an addition to the test. ${ }^{93}$ It received input from Chad Buckendahl, $\mathrm{PhD}$, the board's test and measurement consultant. ${ }^{94}$ Dr. Buckendahl advised "the task force that the board's current examination provides a valid and reliable measure of the technical competence of applicants seeking to practice law in Florida.",95 Dr. Buckendahl also stated that the board's essay questions compared favorably to the MPT questions offered by the NCBE. ${ }^{96}$ The reasoning for that position was as follows:

Although the Board currently labels their constructed response questions as essays, the judgment and abilities being demonstrated (i.e. analysis, evaluation, communicating) are very similar to what would be demonstrated on a PT question. The only difference is that a PT question as discussed by the Task Force would include reference resources/materials that a candidate can use as part of their demonstration of the skills.

As both essay questions and MPT questions required a constructed response, Dr. Buckendahl was not convinced that adding the MPT would provide any assistance in identifying applicants with the desired skills set of a new Florida attorney, although it was recommended that the essay questions could be drafted to be even more "performance like [] . . .."97

Ultimately the MPT was not adopted in Florida. ${ }^{98}$

90 See id.

91 Id.; see generally Virtual Tour, supra note 51 (discussing subjects tested on the Florida bar exam).

92 See Fla. BD. OF BAR EXAM'RS, Sup. CT. Fla., CONSIDERATION OF THE FinAl REPORT OF THE TESTING COMMISSION 5-6 (2009).

93 Id. at $1-11$.

94 See id. at 7.

$951 d$.

96 Id.

97 Id.

98 See generally Virtual Tour, supra note 51 (discussing various components of the Florida bar exam). 
The position that has been taken based on the recommendation of someone holding a doctorate in Quantitative and Qualitative Methods in Education may be psychometrically valid, ${ }^{99}$ but it misses the point at the heart of the law school/bar examination problem. The foregoing evaluation is one sided, in that it asks whether a question can, on its surface, measure certain skills. It completely fails to consider the issue from the largest point of reference, namely, determining the skills that an attorney needs, and how those skills fit into preparation for new attorneys. The narrowly drawn answer here is that the Florida Bar questions may test analysis, evaluation, and communication, and do it well, but that range of skills tested is simply too narrow a focus for today's legal practice, and it is done through too heavily through a doctrinal window. There are two problems a bar exam needs to tackle in changing; one, deciding whether broader skills can or should be tested on the bar exam; and two, if not, determining how can the bar exam can ease pressure on doctrine testing to allow law schools to teach and assess them validly. Without any acknowledgement of the necessity of these broader skills for practice, and a larger plan for students to obtain them, students must study more and more doctrine, no matter how the questions are written-effectively squeezing out the time and space in a curriculum to learn other skills.

The bar exam needs to stop looking at its function of gatekeeping minimally competent lawyers in a vacuum and recognize that new attorneys need to learn far more skills than can be tested on a bar exam. By acknowledging that legal education plays a part in shaping those lawyers, bar examiners need to allow room for law schools to teach the full range of necessary skills, thus working together to ensure that minimally competent attorneys are prepared for practice.

Criticism of the bar exam reached a fever point in $2017 .{ }^{100}$ The disconnect between bar exams testing and the skills needed to practice is well documented. ${ }^{101}$ Specifically, Deborah Jones Merritt, of the Ohio State University Moritz College of Law, published a simple statement in the

99 See Kaufman et al, supra note 11 (explaining how bar examinations can be psychometrically tested).

100 Deborah Jones Merritt et al., Validity, Competence, and The Bar Exam, AALS (2017), https:/www.aals.org/about/publications/newsletters/aals-news-spring-2017/faculty-perspectives/.

101 See id. (describing various sources that address the bar examination not correlating with skills lawyers need in practice). 
AALS Faculty Perspectives: "the bar exam is broken." 102 She clearly indicates the main point - that the bar exam is testing too much and too little-requiring the memorization of hundreds of black letter rules, but ignoring the problem of licensing lawyers who can't perform everyday tasks, such as interviewing clients, composing engagement letters, or negotiating. ${ }^{103}$

Merritt notes that bar examiners indicate that their exam is to assess "minimum competence to practice law." 104 She indicates that the Code of Recommended Standards for Bar Examiners, jointly sponsored by the National Conference of Bar Examiners, the American Bar Association, and the American Association of Law Schools, states that a bar exam should
test the ability of an applicant to identify legal issues in a statement of facts, such as may be encountered in the practice of law, to engage in a reasoned analysis of the issues, and to arrive at a logical solution by the application of fundamental legal principles, in a manner which demonstrates a thorough un- derstanding of these principles. ${ }^{105}$

However, Merritt indicates this definition of minimum competence fails in two ways: it both omits important skills expected of minimally competent lawyers, and it tests too heavily for memorization, despite its own Code warning against that practice. ${ }^{106}$

One solution recently suggested was to look to Upper Canada for improvement in our bar exam process. ${ }^{107}$ In that process, the Law Society of Upper Canada (LSUC) uses a 7-hour multiple-choice test, with 220-240 questions testing a wide range of competencies. ${ }^{108}$ The exam is open book, testing the ability to find and process relevant information, rather than merely memorizing rules, and it tests the ability of lawyers to address real client problems, rather than abstract analytical ones. ${ }^{109}$ The attitude that this exam takes is that candidates may prepare in advance for this test by accessing and preparing the materials ahead of time, and testing the ability to find legal information, which is surely a "key lawyer competency.",10

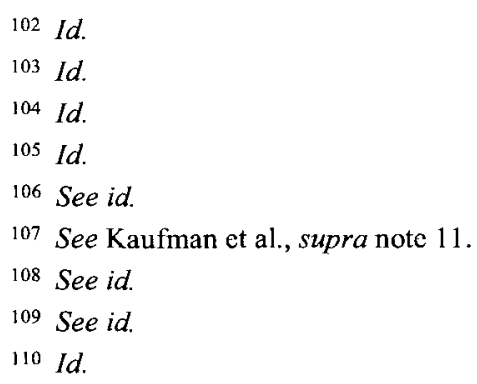


Other competencies included are the ability to understand the pertinent information that a lawyer needs from a client or other source, appropriate use of the trial process, as well as adhering to ethical responsibilities and practical processes in lawyering. ${ }^{11}$ While the exam is not perfect, lessons can be learned about considering the needs of the profession in ensuring that an individual is minimally competent to practice law.

Plenty of advocates have joined the chorus to realize that it "would be malpractice to practice law without looking up and researching answers to client questions and relying on the wisdom and guidance of others."112 There was a 1980 California Bar Exam statistical study that included a clinical evaluation of students as an alternative to the traditional bar exam. ${ }^{113}$ While the results were not definitive, it became clearer how "crucial it is nearly 40 years later for bar examiners to study and implement alternative assessments of skills not currently evaluated by the bar exam." 114

\section{LAW SCHOOL CURRICULUM AND TEACHING NECESSARY COMPETENCIES FOR NEW ATTORNEYS}

Our understanding of what makes an individual ready to enter the legal profession, and a law school's role in contributing to that readiness, has clearly changed dramatically over the years. ${ }^{115}$ A great irony in an overview of the history of legal education is that originally, legal education was largely achieved through apprenticeship training and self-study until

\footnotetext{
111 See id.

112 Paul L. Caron, Allard: The California Bar Exam is the Tip of the Lawyer Licensing Ice-
} berg, TAXPROF BLOG (July 20, 2017), http://taxprof.typepad.com/taxprof_blog/2017/07/allardthe-california-bar-exam-is-the-tip-of-the-lawyer-licensing-iceberg.html.

113 See Stephen P. KLEIN \& ROger E. BOlus, AN ANAlysis of the RELationship Between Clinical Legal SKILls and Bar EXAMINation Results i (GANSK \& Associates 1982).

114 Ben Bratman, Studying Better Ways to Test Bar Applicants for Minimum Competence: Another Reason to Care about the California Bar Exam (besides the cut score debate), BEST PRAC. FOR LEGAL EDUC. BLOG (June 8, 2017), https://bestpracticeslegaled.albanylawblogs.org/2017/06/08/studying-alternative-or-additional-ways-to-test-bar-applicants-for-minimum-competence-another-reason-to-care-about-the-california-bar-exam-besides-the-cut-scoredebate/.

115 See generally Margaret M. Barry et al., The Development of Legal Education in the United States, PILNET (Aug. 10, 2010), http://www.pilnet.org/public-interest-law-resources/11-the-development-of-legal-education-in-the-united-states.html (discussing the history of legal education in the United States). 
the end of 18 th century. ${ }^{116}$ Under the apprenticeship model, an individual would associate and work with a lawyer and receive training in both legal doctrine and the skills necessary to practice. ${ }^{117}$ Thus, the first legal education was experientially based, and it has taken 150 plus years to try to get back to that model. ${ }^{118}$

However, the study of law became seen as an academic field in late 18th and early 19th centuries when colleges began to hire professors of law and create law departments. ${ }^{119}$ As an academic field, the study of law stressed a general education with an academic emphasis on law subjects, not unlike history or economics, and focused on legal doctrine and theory for undergraduates. ${ }^{120}$ Famously, Christopher Columbus Langdell, the Dean of the Harvard Law School faculty, was largely responsible for transforming the law school classroom from a lecture environment to the more familiar, and still very much in use, case method. ${ }^{121}$

In the late 1920 s and early 1930 s, the ABA's campaign for university-based legal education became more successful, and many jurisdictions started to require a degree in law to be admitted to practice. It was at this point that the law became a graduate program rather than undergraduate, and the three-year course of study was established, with a very heavy emphasis on teaching legal doctrine and legal analysis. ${ }^{122}$ Until very recently, the two biggest changes in legal teaching were an increased emphasis on legal research and writing in the first year, along with an explosion of clinical legal education. ${ }^{123}$ More recently, the ABA passed an accreditation standard requiring six credits of experiential education for all law students, which has had a large impact on many curricula. ${ }^{124}$

However, even with these improvements, a standard law school curriculum is still not enough to make new attorneys minimally competent. Other necessary skills for successful practice exist and need to be introduced and learned during 
law school. The Florida Bar Vision 2016 Commission, in studying the future of the profession, identified three categories of skills necessary to success as a new attorney. ${ }^{125}$ This chart developed by the commission divides them by category.

125 See Fla. B. THE Florida BAR Vision 2016: FinAl REPORT 2 (2016), https:/www.floridabar.org/wp-content/uploads/2017/04/vision2016full-final-report-ada.pdf. 


\begin{tabular}{|c|c|c|}
\hline Law Based Skills $^{26}$ & $\begin{array}{c}\text { Non-Law } \\
\text { Related Skills }\end{array}$ & $\begin{array}{l}\text { Professional Identity/ } \\
\text { Attributes Subgroup }\end{array}$ \\
\hline 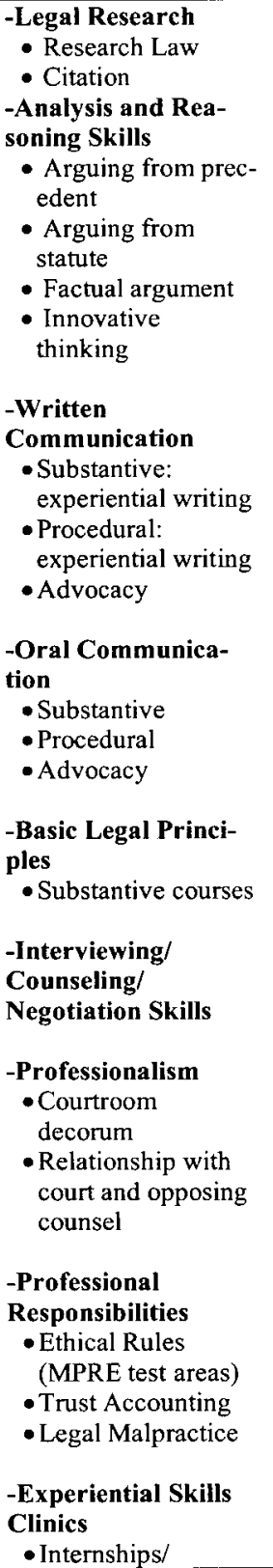 & 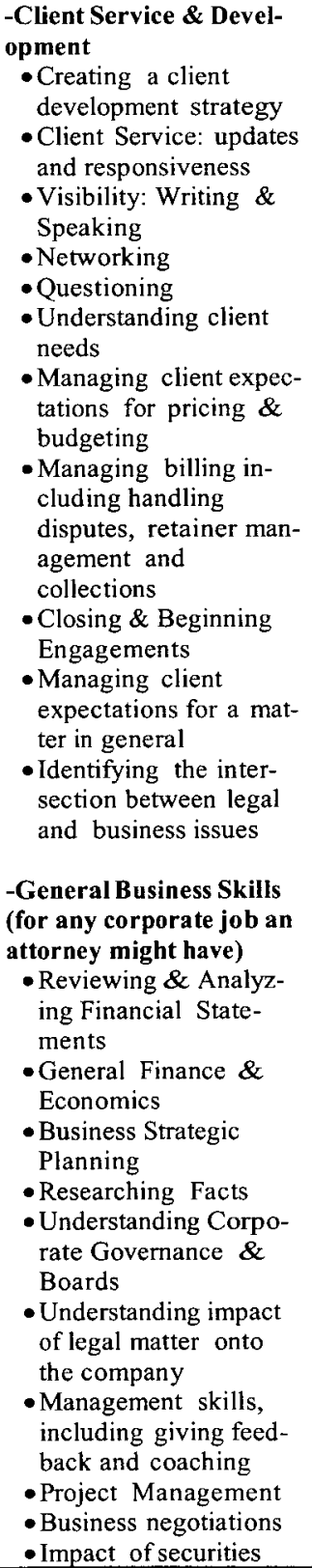 & $\begin{array}{l}\text {-Intrapersonal skills/attributes } \\
\text { Commitment to Professional Devel- } \\
\text { opment toward excellence (lifelong } \\
\text { learner) } \\
\text { - Initiative/Drive/Ambition/Strong } \\
\text { work ethic (internal motivation) } \\
\text { - Integrity/Authenticity \& } \\
\text { Honesty/Trustworthiness } \\
\text { - Passion/Engagement } \\
\text { - Professionalism in Attitude } \\
\text { - Stress/time management } \\
\text { - Open-mindedness, Self-reflection } \\
\text { and Self-regulation (ability to } \\
\text { recognize one's strengths/ } \\
\text { weaknesses and the limits of one's } \\
\text { knowledge/skills) } \\
\text {-Interpersonal skills/attributes } \\
\text { - Ability to perceive, control/manage, } \\
\text { and evaluate } \\
\text { emotions (Emotional Intelligence) } \\
\text { - Civility } \\
\text { - Good listening skills } \\
\text { - Leadership (composite of many } \\
\text { qualities) } \\
\text { - Professionalism in Dress, Speech, } \\
\text { and Manner } \\
\text { - Working with people from diverse } \\
\text { backgrounds } \\
\text { - Cognitive or Process skills/attributes } \\
\text { - Good Judgment/Common sense, } \\
\text { problem-solving } \\
\text { - Recognize and resolve ethical dilem- } \\
\text { mas }\end{array}$ \\
\hline
\end{tabular}




\begin{tabular}{|l|l|l|}
\hline externships & $\begin{array}{l}\text { laws on entities (hedge } \\
\text { - Simulations } \\
\text { compand, publicly held } \\
\text { cinancial Literacy \& }\end{array}$ & \\
Financial Advocacy & $\begin{array}{l}\text {-Communication Skills } \\
\text { - Informal business } \\
\text { writing } \\
\text { - Writing articles } \\
\text { - Presentation skills }\end{array}$ & \\
\hline
\end{tabular}

This commission of academics, practicing lawyers, and judges, agreed on the three categories of skills - of which legal education has clearly focused the most on the first category. Law schools, however, are now becoming interested in more fully developing the second and third categories, with a particular emphasis on helping students develop their professional identity skills during law school. ${ }^{127}$

Recent literature has indicated that the idea of professional identity in education has become pervasive in other areas, such as the clergy and medicine. ${ }^{128}$ Professional formation, what Educating Lawyers referred to as "the law student's third apprenticeship," has left "too much to just happen" in the law school curriculum. ${ }^{129}$ But this is changing. In part, thanks to centers, such as the Holloran Center for Ethical Leadership in the Profession, there now exist legal educational opportunities nationwide, which seek to bring professional identity formation to law schools in a purposeful manner. ${ }^{130}$ But despite these forward steps, looming in the distance is a hurdle for students nearly completely unconnected to that education. That hurdle is a doctrine-based memorization exam.

$\mathrm{We}$, in the legal profession, have a responsibility to teach students to think about the future of the profession. A distinguishing feature of professionals who "have been identified as exemplars by their peers" includes

127 See Honabach, supra note 22, at 50.

128 See Larry A. Golemon, Professional Identity Formation Throughout the Curriculum: Lessons from Clergy Education, 68 MERCER L. REV. 649 (2017); see also Sylvia R. Cruess \& Richard L. Cruess, From Teaching Professionalism to Supporting Professional Identity Formation: Lessons from Medicine, 68 MERCER L. REV. 665 (2017).

129 Louis D. Bilionis, Bringing Purposefulness to the American Law School's Support of Professional Identity Formation, U. ST. THOMAS L.J. (forthcoming 2017) (manuscript at 2), https://ssrn.com/abstract $=2977974$.

130 See id. at 3. 
the ability to become "other-centered," and comprises those who are responsible for regulating the future of their profession. ${ }^{131}$ The result is that "educational interventions to promote identity formation" are an important part of the professional development of students in a peer group. ${ }^{132}$

There has been some pushback in the expansion of law schools' curriculum. ${ }^{133}$ Some have asserted that skills such as legal reasoning, analysis and statutory construction are "best learned in doctrinal courses," and that clinics and simulation courses do not train these skills as well as doctrinal courses. ${ }^{134}$ Another criticism of experiential learning is its inability to go as deep as certain doctrinal subjects, such as taking a basic course in an area followed by a more intensive doctrinal experience. ${ }^{135}$ While there is no question that reinforcement of knowledge is an important step in learning, there is no reason to limit that reinforcement to the doctrinal classroom. Reinforcement through using a doctrine applied real world cases actually brings a level of knowledge that can never be seen in a classroom.

Others have tackled this criticism of experiential education with concrete examples of how all skills, including concerns pertaining to reasoning, analysis, and construction, are used explicitly, and well, in clinical legal education. ${ }^{136}$ An additional rebuttal to these criticisms include the reminder that the delivery of legal services includes the analysis of legal issues; that all aspects of practice, including waiting for court, have educational value; and the understanding that the facts of a client's case cannot be controlled in practice. ${ }^{137}$

131 Muriel J. Bebeau, Stephen J. Thoma \& Clark D. Cunningham, Educational Programs for Professional Identity Formation: The Role of Social Science Research, 68 MERCER L. REV. 591, 596-97 (2017).

132 Id. at 597.

133 See generally Douglas A. Kahn, The Downside of Requiring Additional Experiential Courses in Law School, 31 PROB. \& PROP. MAG. 38 (2017) (discussing the reasoning behind why it is "ill-advised" to require law students to take more experiential courses).

${ }^{134}$ Id. at 41.

135 See id. at 43.

136 See Deborah J. Merritt, What Do Students Do in Clinics?, L. SCH. CAFE (May 17, 2017), https://www.lawschoolcafe.org/2017/05/17/what-do-students-do-in-clinics/.

137 See id. 
It is important to note that this curricular re-thinking is happening against a backdrop of great change in the legal education market. ${ }^{18}$ The legal education landscape in this country, both today and within the past few years, looks quite different than when most law school curricula were originally developed. ${ }^{139}$ There are more law schools, of all kinds, competing for the fewest numbers of students in many years, and yet law schools are struggling to enroll diverse students, or to successfully distinguish applicants using traditional indicators.

There are currently more than $200 \mathrm{ABA}$ fully or provisionally accredited law schools in the United States that grant a J.D. degree. ${ }^{140}$ There are an additional 32 non-ABA accredited law schools in the US. ${ }^{141}$ In some states, such as Florida, the number of law schools has literally doubled in the past twenty years. ${ }^{142}$ At the same time, from 2010-2016, there was approximately a 30\% drop in the number of test takers sitting to take the Law School Admissions Test (LSAT). ${ }^{143}$ Additionally, in the period of time between fall 2005-2015, the number of applicants dropped about $41 \% .{ }^{144}$ Although there was a small rise in 2016 , and a slightly larger rise in 2017, there are more law schools than there used to be, with far fewer applicants, and far fewer matriculants. ${ }^{145}$ Law schools are naturally seeking competitive ways to distinguish themselves, and innovative curricula are on the forefront, though tempered, of course, by having to report and account for their bar passage results.

In addition to the smaller overall numbers, there is no question that LSAT test takers are not equally diverse in all areas, and while there has been very little difference in relation to gender in test takers, there is a

\footnotetext{
138 See generally Blake D. Morant, The Continued Evolution of American Legal Education, 51 WAKE FOREST L. REV. 245, 245-47 (2016) (discussing the changing landscape of legal education, which ultimately "confirms that law schools are modifying their programs of education and, as a result, are preparing students for a demanding, global market").

139 See id.

140 See ABA-Approved Law Schools, A.B.A., http://www.americanbar.org/groups/legal_education/rcsources/aba_approved_law_schools.html (last visited Oct. 20,2017).

141 See Non-ABA-Approved Law Schools, LSAC, http://www.lsac.org/jd/choosing-a-lawschool/law-school-links\#NON-ABA (last visited Oct. 20, 2017).

142 See Florida Law Schools, JuSTIA.COM, https:/www.justia.com/law-schools/florida/ (last visited Oct. 20, 2017).

143 See Total LSATS Administered-Counts \& Percent Increases by Admin \& Year, LSAC, http://www.lsac.org/lsacresources/data/lsats-administered (last visited Oct. 20, 2017).

144 See id.

145 See id.
} 
further disparity with regard to race. ${ }^{146}$ Despite the fact the applicants of color are disproportionately disadvantaged and excluded by the LSAT, the LSAT clearly drives admissions decisions more than any other admissions factor. ${ }^{147}$ Despite the fact that the LSAT is a heavily regulated tool meant to ensure consistency among applicants, and despite disparate testing dates and geographic administration, admissions committees at law schools rely heavily on LSAT scores to evaluate applicants' logical reasoning, analytical, and reading skills, all of which are essential for success in law school. ${ }^{148}$ Based on information released from the Law School Admission Counsel (LSAC), there is both a compression of the range of scores by applicants, as well as a range of scores used to admit applicants into law schools, which results in the similarity of many students - both in terms of skills demonstrated, as well as racial and ethnic background.

However, there still remain rough "categories" of law schools, with the impact of the bar exam impacting each category differently. ${ }^{149}$ Law schools have been described as comprising "three rough clusters: the 'elite' law schools, the 'modal' (most frequently occurring) law schools, and the 'precarious' law schools." 150 These schools are different in terms of the opportunities that they offer for their students, and the post-graduate concerns of those students. ${ }^{151}$ Students in the elite law schools are often admitted largely due to their high LSAT scores. ${ }^{152}$ These students have often mastered academic skills, such as test taking, and thus, either individually or institutionally, are not concerned about the bar exam following graduation. That the bar exam is largely unrelated to all other necessary skills for the practice of law is of little concern for many of these students, or institutions, as they have historically been successful test takers. ${ }^{153}$ For many of these students, however, there is a likely disconnect between the

146 See Susan P. Dalessandro et al., LSAT Technical Report Series, LSAC, https://www.lsac.org/docs/default-source/research-(lsac-resources)/tr-14-02.pdf (last visited Oct. 20, 2017).

147 See Kristen Holmquist ct al, Measuring Merit: The Shultz-Zedeck Research on Law School Admissions, 63 J. LEGAL EDUC. 565, 565 (2014).

148 See About the Law School Admissions Test (LSAT), LSAC, https://www.1sac.org/docs/default-source/publications-(lsac-resources)/about-the-lsat.pdf (last visited Oct. 29, 2017).

149 See Nancy B. Rapoport, Changing the Modal Law School: Rethinking U.S. Legal Education in (Most) Schools, 116 PENN. ST. L. REV. 1119, 1123-25 (2012).

$150 \mathrm{Id}$. at 1119.

151 See id. at 1125.

152 Id.

153 Id. 
accomplishments that landed them in an interview room for a job (a high LSAT score leading to admission at an elite or high modal law school, leading to a high Law school GPA) and demonstrated success on the actual requirements of being a lawyer. However, for many large firms that hire based on GPA and pedigree, the lack of practical lawyering skills are unlikely to hamper their ability to secure these jobs, so there is little incentive to consider making any changes. ${ }^{154}$

But, in many modal and precarious law schools, students are less often selected for interviews at firms who are interested mostly in academic credentials, rather than "hit the ground running" skills - the training that they receive and the disparity of the bar exam can have an enormous impact on these skills. These students may not have demonstrated as much success in traditional academic skills such as test taking, and thus may be more concerned about performance on the bar exam. As such, institutionally, these schools also feel the pressure to assist them. ${ }^{155}$ The very students who are more likely to go into jobs where they would most need all the additional practice ready skills that are not tested on the bar exam are more likely to tilt their academic careers toward ensuring successful bar preparation. ${ }^{156}$ That means focusing more doctrine and memorization, and less on practical lawyer training. ${ }^{157}$

This destructive cycle for these students must stop. The only way to break the cycle is for law schools and bar examiners to join in the task of ensuring minimum competency for attorneys. They need work together to ensure that new attorneys have all the necessary skills of competency, while also ensuring that new attorneys have time to balance their training among all of them. The next section offers a way to accomplish this goal.

\section{LEARNING OUTCOMES}

One way for bar examiners and legal educators to work together to ensure competent new lawyers is for both entities to cooperate on establishing a set of competencies that new attorneys need, and then cooperate on how they will be assessed. In other words-divide and conquer those

\footnotetext{
154 See id. at $1144-45$.

155 See id. at 1136-39.

156 Id.

157 Id.
} 
gate-keeping goals. The most direct and useful way to accomplish this is to leverage the concept of learning outcomes.

\section{A. Learning Outcomes come to Legal Education}

The ABA Standards governing legal education now require the use of learning outcomes and assessments in legal education. ${ }^{158}$

\section{Standard 301. OBJECTIVES OF PROGRAM OF LEGAL EDUCATION}

(a) A law school shall maintain a rigorous program of legal education that prepares its students, upon graduation, for admission to the bar and for effective, ethical, and responsible participation as members of the legal profession.

(b) A law school shall establish and publish learning outcomes designed to achieve these objectives.

\section{Standard 302. LEARNING OUTCOMES}

A law school shall establish learning outcomes that shall, at a minimum, include competency in the following:

(a) Knowledge and understanding of substantive and procedural law;

(b) Legal analysis and reasoning, legal research, problem-solving, and written and oral communication in the legal context;

(c) Exercise of proper professional and ethical responsibilities to clients and the legal system; and

(d) Other professional skills needed for competent and ethical participation as a member of the legal profession.

\section{Standard 315. EVALUATION OF PROGRAM OF LEGAL EDUCATION, LEARNING OUTCOMES, ANDASSESSMENT METHODS}

The dean and the faculty of a law school shall conduct ongoing evaluation of the law school's program of legal education, learning outcomes, and assessment methods; and shall use the results of this evaluation to determine the degree of student attainment of competency in the learning outcomes and to make appropriate changes to improve the curriculum.

In short, learning outcomes "are goals that describe how a student will be different because of a learning experience. More specifically, learning outcomes are the knowledge, skills, attitudes, and habits of mind

158 A.B.A. STANDARDS, supra note 16, at 15, 23.

$159 \mathrm{Id}$, at 23. 
that students take with them from a learning experience." ${ }^{, 160}$ Learning outcomes are judged as to whether they are met by using assessments, tools that "provide us, the instructors, and the students with evidence of how well the students have learned what we intend them to learn."161 While bar examiners and legal educators are well versed in giving assignments, they have not given enough thought as to how they measure the outcomes of those assignments.

What does this ABA Standard mean for law schools? It means that law school curricula are now required to set learning outcomes, for courses individually, programs, or for institutions as a whole, that detail what law students should know at the end of that course, program, or upon graduation. ${ }^{162}$ This new standard comes amidst great national interest in this area. ${ }^{163}$ The push for educational outcomes of college students is so strong, that a bipartisan group of U.S. senators is pushing to repeal the federal ban on tracking outcomes of college students. ${ }^{164}$ The College Transparency Act would provide a picture of how colleges are serving students, including their educational outcomes, seeking to ensure accountability. ${ }^{165}$

In response to these new requirements, many law schools have taken the opportunity to think broadly about what the goal of legal education should be, and have published their learning outcomes demonstrating that they are decidedly not entirely doctrinally based. ${ }^{166}$ A survey was collected regarding law schools crafting learning outcomes and what they are

\footnotetext{
${ }^{160}$ Linda Suskie, Assessing Student LeARnING: A Common SEnSE Guide 117 (2d ed. 2009).

161 Carnegie mellon Univ., Eberly Ctr. for Teaching Excellence \& Educ. INNOVATION, ALIGNING ASSESSMENTS WITH OBJECTIVES, http:/www.cmu.edu/teaching/assessment/howto/basics/objectives.html (last visited Oct. 19, 2017).

162 See A.B.A. STANDARDS, supra note 16, at 15.

163 See Susan Haley Duncan, The New Accreditation Standards are Coming to a Law School Near You-What You Need to Know about Learning Outcomes \& Assessment, 16 J. LEGAL WRITING INST. 605, 608-09 (2010).

164 See Adam Harris, Federal Lawmakers Begin New Push for Student-Outcomes Data, Chronicle Higher Educ.: THE TICKER (May 15, 2017), http://www.chroniclc.com/blogs/ticker/federal-lawmakers-begin-new-push-for-student-outcomes-data/118396.

165 See id.

166 See Neil Hamilton, Formation of an Ethical Professional Identity (Professionalism) Learning Outcomes and E-Portfolio Formative Assessments, 48 U. PAC. L. REV. 847, 850 (2017).
} 
incorporating in terms of legal education. ${ }^{167}$ According to this survey, as of December 23, 2016, 78 law schools had posted learning outcomes on their schools' websites, with 53 of those adopting learning outcomes to include "values that students are expected to understand and integrate into their professional lives." 168 Further broken down, 32 schools adopted a version of a learning outcome "that includes the competency of demonstrating understanding and integration of pro-active professional development toward excellence at the competencies needed to serve clients and the legal system," and 27 more included a learning outcome regarding developing self-awareness and cross-cultural competency. ${ }^{169}$ Other law schools adopted learning outcomes that included teamwork/effective collaboration, professionalism, strong client relationship skills, integrity, honesty, initiative, strong work ethic, diligence, respect for others and leadership. ${ }^{170}$ Clearly, law schools have set the goal that legal education will ensure competency in a wide range of practical skills and values.

At NSU College of Law, we have developed learning outcomes that are core to the entire program of study, as well as ones that may apply to certain courses throughout the curriculum. In addition, NSU College of Law has adopted a broad purpose for legal education:

(Core 1-10)

1. Demonstrate a knowledge of substantive legal doctrine fundamental to this course (e.g., case law, legal concepts, legal principles, regulations and statutes).

2. Identify legal issues and apply legal reasoning and analysis to solve problems in a logical and structured manner to issues covered in this course.

3. Communicate orally or in writing, or both, the legal reasoning and analysis regarding issues covered in this course.

4. Research legal issues thoroughly and efficiently.

5. Demonstrate a proficiency in reading critically the materials assigned for this course.

6. Understand the obligation to adhere to the values of the legal profession (e.g., (1) providing of competent representation, (2) striving to promote justice, fairness, and morality, (3) striving to improve the profession, and (4) engaging in professional self-development).

\footnotetext{
167 See id.

168 Id.

$169 \mathrm{Id}$.

170 See id. at 851.
} 
7. Demonstrate ethical and practical judgment and active listening skills in communications (e.g. with clients, attorneys, and related parties).

8. Use technology to meet ethical duties of the legal profession (e.g. to address duties of confidentiality for all communications, to fulfill filing and other judicial obligations, and to keep abreast of technologies that affect accuracy of information provided to clients).

9. Anticipate, recognize and resolve obligations ethically.

10. Demonstrate self-directed learning practices for life-long learning.

(Additional Competencies 11-32)

11. Demonstrate commitment and engagement when providing legal services.

12. Demonstrate creativity and innovation when providing legal services.

13. Use stress management techniques.

14. Develop business development skills, (e.g. attracting clients, retaining clients, entrepreneurship, networking, mentoring, and business development skills).

15. Demonstrate effective client counseling when providing legal services.

16. Demonstrate effective negotiation strategies and styles appropriate for client representation.

17. Demonstrate cultural competency and cultural empathy.

18. Demonstrate effective team participation (e.g., collaboration, management, and support).

19. Demonstrate factual investigation, interviewing, and questioning skills.

20. Demonstrate public communications skills.

21. Demonstrate the following pre-trial litigation skills: drafting of pleadings, discovery, and motion practice.

22. Demonstrate the following trial litigation skills: witness examination, strategic use of evidence, developing and delivery opening statements and closing arguments.

23. Demonstrate the following appellate litigation skills: understanding the appellate process, effective brief writing, effective oral argument.

24. Demonstrate transactional planning and drafting skills (e.g., effective use of written communications to clients or third parties, completion of closing documents, and creation of contracts or other documents that effectively translate deal terms or intent).

25. Demonstrate the skills, strategies and procedures used in transactional practice (e.g. due diligence, risk management, client counseling and problem solving through drafting). 
26. Demonstrate the skills, strategies and procedures used in mediation.

27. Demonstrate effective organization and management of legal work.

28. Demonstrate strategic planning skills.

29. Demonstrate effective process management skills (e.g. time management, project management, and organization of work product, including one's own work, the work of staff, and the work of colleagues).

30. Demonstrate quantitative literacy (e.g., accounting and finance reporting, statistical reporting, and competency to apply basic finance principles).

31. Demonstrate the ability to see the world through the eyes of others.

32. Dempnstrate client relationship, management, and stewardship proficiency.

These outcomes clearly go well beyond legal doctrine to embrace the research on the practical skills that are needed by new attorneys. The next important step is to determine whether these outcomes are met. It is not enough to set a goal for your course of study - a law school must determine whether students are actually meeting those goals.

Assessments must be aligned with outcomes - in other words, they are the feedback, graded or ungraded, received from students in order to ascertain whether the learning outcomes are being met. Assessments are generally considered of two kinds: formative and summative. The former is meant to give feedback in the process of meeting the learning outcome, and the latter is used to find out at the end of the educational experience whether the learning outcome was met. A popular saying is that when the chef tastes the food, it is a formative assessment; when the restaurant customer tastes it, it is a summative assessment. ${ }^{172}$

For many years, the list of competencies of a course of study at a law school was narrow - doctrine, analysis, reasoning - all skills that can and are measured by traditional law school doctrinal exams, and ultimately,

171 See Adopted Learning Outcomes, Nova Se. Coll. L. (2016) (on file with the Elon Law Review).

172 See Jeffrey Billard, Formative Assessment: When the Cook Tastes the Soup . . . ., TEACHING THROUGH THE ARTS (July 23, 2011, 12:51 PM), http://teachingthroughthearts.blogspot.com/2011/07/formative-assessment-when-cook-tastes.html. See generally Amos Ilya, Formative and Summative Assessment in Educational Enterprise, 5 J. EDUC. \& PRAC. 111 (2014) (discussing the relationship between formative and summative assessments in education). 
for an institutional success measurement, on a bar exam. ${ }^{173}$ For a long period of time, many law schools referred to the bar exam as their assessment tool to determine that success. ${ }^{174}$ However, it is now easy to see that we understand the value of including more practical skills in legal education than are, or could be, tested on a bar exam. As such, law schools have the responsibility to measure whether students have reached these competencies in other ways. ${ }^{175}$ However, the bar exam largely only measures those same traditional skills: doctrine, analysis, and reasoning. Yet, the number of hours that an individual must study during law school in order to prepare for the bar exam is disproportional to the weight those learning outcomes carry, as set by legal educators.

As law schools actively work to shift and create learning outcomes that align with the fundamental skills necessary for the practice of law, and create assessments in coursework tied to these new learning outcomes, the result should be that the students achieving high grades on these assessments also demonstrate mastery of the skills that are directly tied to competencies for new attorneys, which ultimately demonstrate that they are ready for practice. In other words, when employers choose a student with a high GPA to interview, they should know, at a school that has learning outcomes derived from skills based competencies, whether that student has excelled in the skills that are needed for the practice of law, and not solely doctrinal or traditional academic testing. These competency assessments should be as important as the bar exam for new attorneys. But, of course, they are not-the doctrinal-based memorization exam is the lone gatekeeper. This disconnect must stop. Law schools and bar examiners must set joint learning outcomes to determine minimum competency, and they must jointly determine how examinees will be assessed, in order to allow prospective attorneys into licensed practice.

The best place for the bar examiners and law schools to begin working together to draw these wider, cooperatively planned learning outcomes, are from the practicing lawyers themselves. One of the key factors needed for experiential education to be fully embraced, beyond the ABA

173 See Janet Motley, A Foolish Consistency: The Law School Exam, 10 NovA. L.J. 723, 760 (1986).

${ }^{174}$ See generally Jay Conison, Success, Status, and the Goals of a Law School, 37 ToL. L. REV. 23, 26 (2005) (analyzing the measurement and metrics of success for a law school).

175 See generally Terri Mottershead \& Sandee Magliozzi, Can Competencies Drive Change In The Legal Profession?, 11 U. ST. THOMAS L.J. 52 (2013) (discussing the "competency movement" in the legal industry). 
required 6 credits of education, is making students competitive for jobs in today's job market by possessing concrete practice skills, with the knowledge "that law firms are no longer willing to undertake the expense of training recent graduates." 176 The following list is a guide for law schools and bar examiners considering making their learning outcomes align with the needs of the profession. These needs include: (1) problem solving; (2) legal analysis and reasoning; (3) researching the law; (4) fact investigation/finding; (5) communication, both written and oral; (6) questioning and interviewing; (7) negotiation; (8) dispute resolution procedures; (9) organization and management of legal work; (10) resolving ethical dilemmas; (11) influencing and advocating; (12) diligence; (13) integrity/honesty; (14) stress management; (15) technologically adept; (16) quantitatively trained ${ }^{177}$ (including economic sophistication; understanding the analysis of decision-making; game theory; and accounting and financial knowledge ${ }^{178}$ ); (17) collaborative; (18) professional and interpersonal communication skills; and (19) client-centered skills.

This list is far from complete, but the list comprises the skills that a new attorney needs to be successful in the practice of law. How many of these skills can be taught? All of them. How many are taught? Far fewer students likely know all of these skills, compared to general knowledge of the rule against perpetuities, despite the fact that they will likely use all of the listed skills immediately, and will rarely need "the rule." ample of an additional competency that has often been ignored in law school, but has been identified as an important one for new attorneys, is time management training. ${ }^{180}$ "Time famine," which is the belief that there is never enough time to complete everything that needs to be done, is a long recognized attorney problem, for which training has been urged for many years. ${ }^{181}$ While time management in legal education is well documented, it is important to note that the ability to manage time in practice

176 Christinc Cerniglia Brown, Is Experiential Education Simply a Trend in Law School or Is It Time for Legal Education to Take Flight?, 60 FED LAw. 42, 44 (Aug. 2013).

177 See David E. Van Zandt, Foundational Competencies: Innovation in Legal Education, 61 RUTGERS L. REV. 1127, 1144 (2009).

178 See Howell E. Jackson, Analytical Methods for Lawyers, 53 J. LEGAL EDUC. 321, 323-24 (2003).

179 See generally Lucas v. Hamm, 364 P.2d 685 (Cal. 1961) (concluding that an attorney did not breach the ordinary duty of care when improperly applying the rule against perpctuities).

180 See Christine P. Bartholomew, Time: An Empirical Analysis of Law Student Time Management Deficiencies, 81 CIN. L. REV. 897 (2013).

181 Id. at 900 . 
and balancing client needs, billable hour requirements and other scheduling needs are critical skills needed for practice. ${ }^{182}$ The "first and more fully developed" instruction in time management should be in all law schools to prepare graduates for handling this crisis when they get to practice. ${ }^{183}$ Learning to master a calendar and break down tasks can occur in any class, but a real life way to learn time management is through clinical experiences.

Others have tried stepping in to fill the void of educating new attorneys. ${ }^{184}$ The Corporate Legal Operations Consortium markets a Legal Operations Career Skills Toolkit, its purpose being to help "individual and legal departments evaluate and develop legal operations skills." 185 The premise is that lawyers should be able to engage in a discussion about technology tools and skills, and should be able to improve efficiency and work product quality by using technology. ${ }^{186}$ The list of skills include business operations, date analysis and reporting, e-Discovery, financial, communication, innovation management project management and teamwork. ${ }^{187}$ In fact, the twelve competences that optimize legal services delivery include strategic planning, financial management, vendor management, data analytics, technology support, alternative support models, knowledge management, growth and development, communications, global data governance, records management, litigation support and cross functional alignment. ${ }^{188}$ These are labeled as core competencies and should be part of a vibrant law school curriculum, rather than be outsourced or pushed to the side to study more doctrine that an attorney can look up up in an instant using current technology.

\footnotetext{
182 See id. at 909.

183 Id. at 937.

184 See Daniel W. Linna, Jr., CLOC Legal Operations Career Skills Toolkit: Lawyers, Your Clients Value Legal Service Delivery Skills, LEGALTECH LEVER (May 2, 2017), http://www.legaltechlever.com/2017/05/cloc-legal-operations-career-skills-toolkit-lawyers-clients-valuc-legal-service-delivery-skills/.

$185 \mathrm{Id}$.

186 See id.

187 See id.

188 See Zach Warren, The 12 Core Competencies that Define the Future of Legal Operations, LAW.COM (May 8, 2017), http://www.law.com/sites/almstaff/2017/05/08/the-12-core-competencies-that-define-the-future-of-legal-operations/?slreturn $=20170815202551$.
} 
In another vein, law schools are being encouraged to create best practices for detecting and assisting students in crisis-one specific crisis includes undergoing psychological distress, which can lead to problems with well-being, both as a student, as well as later members of the profession. ${ }^{189}$ Such best practices can include providing training to faculty members relating to mental health and substance use disorders, adopting attendance policies to better allow faculty to detect students who may be in crisis, and providing mental health and substance use resources throughout the curriculum, as well as developing a well-being curriculum and organizing wellness events. ${ }^{190}$ The resulting question is whether the well-being of attorneys, and knowing how to maintain such well-being, is a minimum competency of new lawyers as well. One ABA Task force seems to indicate that it is. ${ }^{191}$ Moreover, there is research that shows that before law school, law students are actually healthier than the general population, both physically and mentally, but are later marked by depression, negative moods, and physical symptoms. ${ }^{192}$ It is clear that while law schools are not helping students currently prepare for the profession, they are also negatively impacting their ability to function in that profession. ${ }^{193}$

The struggle to determine the place that encompasses the teaching of non-doctrinal, traditional skills, as well as how law schools are to achieve this goal, dates back to the 1950 s. ${ }^{194}$ Additionally, surveys going back more than 15 years list the ability to communicate as a high-ranking skill, along with legal analysis and reasoning. ${ }^{195}$ Yet, practical skills have still taken a back seat to doctrine and memorization. More recent concerns

189 See ABA National TASK ForCe ON LAWYER WELl BEING: CREATING A MoVEMENT TO IMPROVE WELL-BEING IN THE LEGAL PROFESSION, A.B.A. 1, 36 (2017), https://www.americanbar.org/content/dam/aba/images/abanews/ThePathToLawycrWellBeingReportRevFI-

NAL.pdf.

190 See id. at 36-37.

191 See id.

192 See id.

193 See Scott Fruehwald, Why Professional Identity Training Is So Important, LEGAL SKILLS PROF. BLOG (July 18, 2017), http://lawprofessors.typepad.com/legal_skills/2017/07/why-professional-identity-training-is-so-important.html.

194 See Dianne Molvig, Preparing for Practice, 74 WIS. LAW. 1 (2001) http:/www.wisbar.org/newspublications/wisconsinlawyer/pages/article.aspx?volume=74\&issue $=7$ \&articleid $=21715$.

195 Id. 
have included that new lawyers need more common sense, streets smarts, thinking on one's feet, and problem solving skills. ${ }^{196}$

That is not to say that doctrine is not an important part of the competency of new attorneys. But the question of many critics of legal education is "when will law schools change," or "when will law schools incorporate, more fully, the kinds of changes that can ensure that new lawyers approach their careers equipped with a spirit of professionalism, competence and integrity, and with a genuine drive to demonstrate ethical behavior in all of the actions as attorneys?"197 The answer is, for most law students, when there is room in the curriculum to teach these practical skills, without the pressure of the vast amounts of legal doctrine tested on the bar exam forcing students to focus principally on legal doctrine during law school. Only then will legal education produce the most competent attorneys.

This is the crux of the problem. How is an exam that is focused on memorizing doctrine contributing proportionally to meeting the outcome measures of a program of legal education that are so much broader? Of course, the answer is that it isn't, but rather, it is measuring just one small component of the program. The licensing exam that is meant to ensure lawyers have minimum competencies of new attorneys not only ignores most skills needing to be measured, but also puts such pressure on law school curricula, as to make these skills harder to include in good curricular planning.

Therefore, cooperation through joint learning outcomes and reasonably proportioned assessment is necessary for the future of the profession. It has been pointed out that the bar exam "retests" much of a law school curriculum, and that an entire body of work over three or four years by a student may be a better way to show outcome measurement of competence than a two or three day event. ${ }^{198}$ Together, such assessments should show competency in measuring these broad, necessary skills.

The production of new lawyers has too long been compartmentalized. First, students experience a legal education, which includes a lot of foundational work, and "thinking like a lawyer."199 Then, students layer

\footnotetext{
196 See id.

197 Steven C. Bennett, When Will Law School Change?, 89 NEB. L. REV. 87, 88 (2010).

198 See Barnhizer, supra note 8, at 292.

199 See Emily Calhoun, Thinking Like a Lawyer, 34 J. LEGAL EDUC. 507, 507-12 (1984).
} 
on doctrine upon doctrine, writing timed essays on a wide variety of subjects, in preparation for two months of cramming to pass a bar exam. This preparation includes practicing multiple choice and essay writing, half of which include national rules, along with a healthy dose of rules that the average lawyer will never see in practice - all of which could be researched in an instant-all so new attorneys can finally get a job and through actually working, learn how to "be" a lawyer.

The legal education portion of this manufacturing process needs to unseal the "independent and hermetically sealed system with scant connection to the competitive conditions of the real world" ${ }^{200}$ and reconnect it into the pipeline of bar exam to practice. The best starting point to do this would be to better align legal education and the bar exam with the practice of law by using learning outcomes.

As stated, the best way to determine minimum competence-a task that should be completed jointly by legal educators and bar examiners-is using a job analysis. This task should not be foreign to bar examiners, as the National Conference of Bar Examiners already sanctioned it in 2012 . $^{201}$ However, the connection between those results and the current bar exams given is minimal. It is clear that knowledge of research methods, fact gathering, negotiating and interviewing were used by more than $85 \%$ of new lawyers. ${ }^{202}$ Additional surveys of new lawyers assessing these kinds of skills showed that many lawyers simply do not meet a basic standard needed to properly assist clients. ${ }^{203}$ This disconnect was recognized but not fixed. Unfortunately, working alone, the bar examiners cannot fix the problem - they must work together with legal educators.

Ultimately, the question is not even whether the bar exam is testing these subjects, but whether law students, becoming new lawyers, are learning them in any venue. As demonstrated, law school is ready and rife with opportunities to learn these skills, but the pressure of memorization is putting these important aspects on the backburner for many students, who indicate that they can learn these practical skills later, which many new graduates will note are completely useless if they cannot pass the memorization based, subject heavy bar exam. A 1992 study of MBE questions considering whether they were based in legal reasoning or memorization,

\footnotetext{
200 Barnhizer, supra note 8 , at 260.

201 See Merritt et al., supra note 100.

202 See id.

203 See id.
} 
indicated that those two skills were balanced in most questions. ${ }^{204}$ Therefore, those taking the bar exam must have memorization of doctrine before applying legal reasoning, putting further weight on the doctrine aspect of this exam, and further weight on just one learning outcome needed for success in practice. ${ }^{205}$

One state has already taken steps to ensure that students have more than doctrine when entering practice. ${ }^{206}$ New York State, which has recently adopted the UBE test, requires a series of other requirements for bar admission in addition to this admittedly largely doctrinal test. ${ }^{207}$ First, as noted earlier, they have adopted a state law competency exam to ensure applicants engage and familiarize themselves with New York specific law in addition to the general testing. ${ }^{208}$ However, most importantly, they have gone further, with two additional requirements. First, each applicant to the New York Bar has to complete 50 hours of pro bono work before being admitted to the bar. ${ }^{209}$ While this requirement arose largely out of the access to justice crisis, the report on the requirement also notes that it helps prospective attorneys gain valuable skills. ${ }^{210}$ Second, the state has also added a skills competency requirement. ${ }^{211}$ Students have five pathways to demonstrate that they have the skills necessary to become admitted to the bar and none of them have anything to do with the doctrinal test that they must pass. In short, the bar examiners have gone around the issue of doc-

\footnotetext{
204 Id.

$205 \mathrm{Id}$.

206 See generally THE N.Y. STATE BD. OF L. EXAM'RS, NEW YORK STATE BAR EXAM INFORMATION GUIDE (2017), http://www.nybarexam.org/TheBar/NYBarExamInformationGuide.pdf (discussing the different requirements necessary for applicants to the New York Bar must achieve in addition to learning legal doctrine).

207 See Uniform Bar Examination, New York Law Course \& New York Law Exam, N.Y. STATE BD. L. EXAMINERS, http://www.nybarexam.org/UBE/UBE.html (last visited Dec. 7, 2017).

208 See id.

209 See Admission Information, N.Y. STATE BD. L. EXAMINERS, http://www.nybarexam.org/Admission/Admission.htm (last visited Dec. 7, 2017).

210 See N.Y. Courts, Advisory COMm. on N.Y. State Pro Bono B. Admission REQUIREMENTS, REPORT TO THE CHIEF JUDGE OF THE STATE OF NEW YORK AND THE Presiding Justices OF THE FOUR APPEllate DIVISION DEPARTMENTS 1 (2012), http:/www.nycourts.gov/attorneys/probono/ProBonoBarAdmissionReport.pdf.

211 See Frequently Asked Questions for New York's Skills Competency and Professional Values Bar Admission Requirement (Rule 520.18), NYCOURTS.GOV 4 (Mar. 2016), http://www.nycourts.gov/ctapps/news/skills.pdf.
} 
trinal/skills testing and dealt with the problem directly. Two of the pathways involve a law school directly certifying that a student has the necessary skills or a minimum number of experiential credits. ${ }^{212}$ Students certify their completion of the last three pathways by submitting information indicating that they have satisfied the minimum number of experiential credits, or that have obtained the equivalent work experience. ${ }^{213}$ Such other pathways include meeting the Pro Bono Scholars requirements, apprenticeship requirement, or have prior legal practice lawfully elsewhere. ${ }^{214}$

In short, New York is stating that doctrine is not enough to be a member of the bar, and they have done several things to remedy the issue. One such action is switching to testing the UBE, which limits the amount of doctrine students need to cover in law school. Secondly, they have made the state specific portion of the exam open book, thus making it more about learning and reading and finding law than rote memorization. Thirdly, applicants are required to have actual work experience through pro bono work. Finally, the exam requires a student to demonstrate that they used the specific time in law school not on memorization, but to take experiential classes and/or gain more actual work experience. Not only does this combination is maximize prospective attorneys' time, but it also attempts to strike a balance between doctrine and skills, in order to produce new attorneys who are accomplished in both.

Other state bars should follow suit with the spirit of this requirement, stop overburdening prospective attorneys with doctrine, and make room in their curriculum for a skills requirement. The first step is to reduce the scope of doctrine tested on a bar exam. This simple step will allow law schools, who are ready, willing, and able partners, to help ensure that students have the opportunities, and are able to take advantage of them, in order to gain a wide range of competencies. State bars have the power to both encourage and require that students undertake this kind of important training, but they must take the first step by lifting the burden of doctrine based testing.

It is clear that law schools and the boards of bar examiners should cooperate to detail the learning outcomes of new attorneys. They should then determine which of these learning outcomes are best assessed by a

$212 I d$ at 5.

$213 \mathrm{Id}$.

214 Id. 
one-time test, and which are best determined if met over a multi-year course of study. Once those learning outcomes have the proper assessments tied to them, each assessment should be crafted to allow a future professional the time to learn the skills, values and doctrine across all of the learning outcomes, without one test or body of knowledge drowning the others, as is currently happening with the bar exam right now.

\section{CONCLUSIONS}

A retired Colorado Supreme Court Justice has indicated that "the gap between the skills the legal profession needs in today's market and the attorneys law schools are producing is not only widening but will be difficult for legal education to overcome. ${ }^{, 215}$ The Justice is right in expressing concern about the widening gap, but wrong in assigning blame on legal education alone. A major root of this problem is the distance between the goals of many law schools of turning out lawyers with the skills needed for practice and the substance tested on most bar exams.

It is clear-the goal of ensuring the competency of new lawyers is best served by legal educators and bar examiners working together to develop a series of core competencies of new lawyers. From there, assessments can be planned and allocated proportionally. Can we, together, come up with a job sharing arrangement that preserves the best of what each of these entities do and eliminate that tug of war?

In theory, not only can we accomplish this task, but the map to do so is clear using educational tools easily available to us-learning outcomes. However, the reality of this goal is obscured by bar politics, protectionism, and the egos of those involved. Only by putting these peripheral and petty foci aside for the good of the profession will we turn the corner and protect the public by turning out-jointly - attorneys who can truly protect and serve the public with their competence. The path is clear for the future of the profession to be "digging" in the right place.

215 Marilyn Odendahl, Character Better Predictor of Lawyering Success, Panel Says, IND. LAW. (May 17, 2017), http:/www.theindianalawyer.com/articles/43706-character-better-predictor-of-lawyering-success-panel-says. 
